\title{
S05401
}

\section{数十 $\mathrm{kHz}$ フラッピング噴流発生薄型デバイスの基礎特性}

\section{Fundamental Characteristics of Flat Device Generating Jets Flapping at Several Tens of kHz}

○正 半田 太郎*1, 藤村育大*1

Taro HANDA*1, Ikuhiro FUJIMURA*1

*1 豊田工業大学 Toyota Technological Institute

Key Words : Fluidic Oscillator, Flapping Jet, Flow Control, Supersonic Flow, Boundary Layer

近年，フラッピング噴流（スウィーピングジェットと呼ばれることもある）(1)の様々な応用研究がなされてい るが，フラッピング噴流を境界層に作用させると，境界層のはく離の抑制に大きな効果があることを報告した研 究がある(2).この研究では, 流速 $45 \mathrm{~m} / \mathrm{s}$ の自動車模型後部の境界層流れにフラッピング噴流を作用させ，噴流の フラッピング周波数は 0.6 2.4kHzである. 著者らのグループではフラッピング噴流を用いた流速数百 $\mathrm{m} / \mathrm{s}$ の遷音 速／超音速境界層流れの能動制御を目的としている.しかしながら，遷音速／超音速流れでは数 $\mathrm{kHz}$ 以下の周波 数でフラッピング噴流を発生させても，フラッピング運動の波長が長くなりすぎて効果的ではない. 過去に数十 $\mathrm{kHz}$ の脈動噴流を作用させることで高亜音速噴流の騒音低減に成功した例(3)や数十 $\mathrm{kHz}$ のレーザーエネルギー付 加によってインテークバズの低減に成功した例(4)があることと，前述したように数 $\mathrm{kHz}$ でフラッピング運動する 噴流が数十 $\mathrm{m} / \mathrm{s}$ の境界層流れ制御に有効(2)であることを併せて考えると, 数十 $\mathrm{kHz}$ でフラッピング 運動する噴流 が遷音速／超音速流れの境界層制御に大きな効果をもたらすことが期待できる．また，フラッピング噴流を用い ると運動量を流れに直接付加できるので, エネルギー付加の能動制御で必要なエネルギーから運動量への変換を うながすトリガ（例えば，衝撃波）の必要がなく，変換の際のエネルギー損失も生じない.

著者らのグループでは, 高速流れの能動制御を目的として, キャビティ内の共振で駆動される薄型のフラッピ ング噴流発生デバイスを提案した ${ }^{(5)}$. 本デバイスの特徵は, 数十 $\mathrm{kHz}$ でフラッピング運動する数 $\mathrm{mm}$ スケールの 噴流を発生させられるだけでなく，発生する噴流の質量流量を変えずに周波数を制御できることである．これま でのフラッピング噴流発生デバイスでは，流量を変えることにより噴流のフラッピング周波数を変える機構にな っている.制御対象の流れ場は, 発生寸る噴流の質量流量と周波数のどちらにも影響を受けると考えられるので, 従来のデバイスを用いると最適な制御を行うことが困難であると考えられる．著者らのグループは質量流量一定 のまま，フラッピング噴流が発生するデバイスを提案したが，デバイス形状がフラッピング噴流の運動状態に与 える影響がまだ明らかになっていない，そこで，本研究では，フラッピング噴流発生デバイスの出口高さに着目 し，この高さを変えてフラッピング噴流の周波数特性を調べ，運動状態を可視化した．その結果，デバイス出口 高さは噴流のフラッピング周波数とフラッピング運動に大きな影響を与えることが明らかになった.

\section{文献}

(1) Raghu, S., "Fluidic Oscillators for Flow Control," Experiments in Fluids, Vol. 54, No. 2 (2013), Paper 1455.

(2) Metoka, M., and Gregory, J. M., "Drag Reduction on the 25-deg Ahmed Model Using Fluidic Oscillators," Journal of Fluids Engineering, Vol. 137, No. 5 (2015), Paper 051108.

(3) Upandhyay, P., Gustavsson, J. P. R., and Alvi, F. A., "Development and Characterization of High-Frequency ResonanceEnhanced Microjet Actuators for Control of High-Speed Jets," Experiments in Fluids, Vol. 57, No. 5 (20160, Paper 88.

(4) Myokan, M., Kubota, A., Iwakawa, A., and Sasoh, A., "Repetitive Energy Deposition at a Supersonic Intake in Subcritical and Buzz Modes," AIAA Journal, Vol. 58, No. 1 (2020), pp. 107-117.

(5) Handa, T., Fujimura, I., "Fluidic Oscillator Actuated by a Cavity at High Frequencies," Sensors and Actuators A: Physical, Vol. 300 (2019), Paper 111676. 